\title{
Secrets of Mammary Stem Cells Secretome
}

\author{
Ratan K Choudhary* \\ Guru Angad Dev Veterinary and Animal Science University (GADVASU), INDIA
}

Submission: April 13, 2018; Published: June 12, 2018

*Corresponding author: Ratan K Choudhary, School of Animal Biotechnology, Guru Angad Dev Veterinary and Animal Science University (GADVASU), Ludhiana - 101004, INDIA, Email: vetdrrkc@gmail.com; ratankumar@gadvasu.in

\begin{abstract}
The role of mammary stem/progenitor cells and its secreted proteins in therapeutic application has not been evaluated yet. Here, author reviewed information pertaining to secreted proteins of mammary epithelial cells and mammary stem/progenitor cells and supported their ideas that secretome could potentially be explored for natural antimicrobials against supportive therapy of bovine mastitis.

Keywords: Mammary stem cell; Secretome; Mastitis; Bovine; Spectrophometer; Proteins; Laboratory; Lactoferrin; Receptors; Biomarkers; Pacific; Population; Antibiotics; Progenitor cells

Abbreviations: HMEC: Human Mammary Epithelial Cells; CM: Conditioned Medium; EGFR: Epidermal Growth Factor Receptor; AFDC: Adherent Fraction Derived Cells; MDC: Mammosphere Derived Cells; TGFß: Transforming Growth Factor Beta; MDBK: Madin Darby Bovine Kidney Epithelial; LPS: Lipopolysaccharides
\end{abstract}

\section{Opinion}

Secretome are the cell secreted proteins released in the cell extracellular space. Groups of proteins present in the secretome are involved in signalling and cell communications. Study of such proteins, thus would be helpful in understanding the niche of the cell. Researchers of Pacific Northwest National Laboratory, Washington probably was the first group which demonstrated secretome of human mammary epithelial cells (HMEC) in 2008 [1]. They identified secretome of human mammary epithelial cells (HMEC)-conditioned medium (CM) cell lysates and showed regulation of matrix metalloproteases through epidermal growth factor receptor (EGFR). In 2009, Simpson and coinvestigators have profiled three different secretome of basal MaSC, luminal progenitors and mature luminal cell lines. In this study, in addition to enriched expression of ephrin receptors and integrins, the activity of Wnt signalling pathway was uniquely detected in the MaSC [2]. In a recent publication of Scientific Reports journal, researchers from Cornell University, Ithaca, NY has defined secretome of mammosphere derived MaSC and opened up new doors for the possible treatment of bovine mammary gland infections [3].

For their studies, the team isolated cultured two different populations of bovine mammary cells- adherent fraction- derived cells (AFDC) and suspension mammosphere-derived cells (MDC). These two cell population were immunopheno typically different as analyzed by various cell surface markers. However, the expression of CD44 and CD49f was higher in MDC CM than the AFDC CM. Level of CD29 was high in CM of both these cells. Proteome analyses of AFDC and MDC CM, using mass spectrophometer, revealed 347 and 537 matched proteins and peptides functionally related to defense and immunity and tissue regeneration like angiogenesis and cell migration. Furthermore, two antimicrobial proteins namely lactoferrin and cathelicidine have been validated and quantified using Western blot (Figure 1) and observed differential expression of the proteins in $\mathrm{CM}$ of MDC versus AFDC. Two angiogenesis factors namely, angiopoetin 1 and vascular endothelial growth factor alpha, angiopoetin 1 showed high expression level in MDC CM. Likewise, levels of proteins involved in cell migration (transforming growth factor beta (TGF $\beta$ ), Insulin-like growth factor- 1 and hepatocyte growth factor) were estimated in the $\mathrm{CM}$ and found that the concentration of TGF $\beta$ was high in CM of MDC. TGF $\beta$ induces epithelial cell to mesenchymal type and promotes cell migration. Taken together, this study showed CM of AFDC and MDC contains various proteins which have roles in tissue regeneration and immune defence of the host. 
a

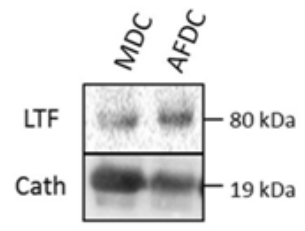

b
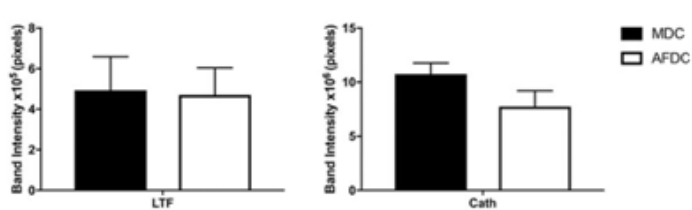

Figure 1: Mammosphere derived cells (MDC) and adherent fraction derived cells (AFDC) both secret anti-microbial peptides namely lactoferrin (LTF) and cathelicidine (Cath) detected in lysates of MDC and AFDC

(a)with measuring band density of two anti-microbials.

(b) Image adapted from [3] which is an open access article and requries no permission upon original citation.

Interestingly, proteins of AFMC and MDC also contained factors which protects bacterial toxin-induced MEC death. Loss of MEC damage is an important consequence of mastitis and it is induced by the toxins of Gram-positive bacteria and lipopolysaccharides (LPS) of Gram-negative bacteria. A significant reduction in growth of bacteria (measured by optical density) was observed when Madin-Darby Bovine Kidney Epithelial (MDBK) cells were grown in presence of Klebsiella (a Gram-negative bacteria) and Staphylococcus aureus (a Grampositive bacteria) in presence of MDC CM. The researchers also evaluated shelf-life of MDC CM for one week and found that frozen CM is biologically effective on MDBK cell migration. The storing of CM for long time would be advantageous for future clinical use in mastitis management even at remote places.

In summary, these studies providing rationale for the potential use of MDC secretome as supportive or adjunct therapy in bovine mastitis. Secretome could be an ideal biological source for naturally occurring anti-microbial and potentially beallogenically safe like antibiotics. In future, an important follow-on studies should include evaluation of novel proteins as biomarkers and identification of newly identified proteins with no to little annotations. In vivo application of MDC secretome in management of naturally occurring bovine mastitis, also warranted future investigations.

\section{References}

1. Jacobs JM, Waters KM, Kathmann LE, Camp, II DG et al. (2008) The mammary epithelial cell secretome and its regulation by signal transduction pathways. J Proteome Res 7(2): 558-569.

2. Ji H, Goode RJA, Vaillant F, Mathivanan S, Kapp EA, et al. (2011) Proteomic profiling of secretome and adherent plasma membranes from distinct mammary epithelial cell subpopulations. Proteomics 11(20): 4029-4039.

3. Ledet MM, Vasquez AK, Rauner G, Bichoupan AA, Moroni P et al. (2018) The secretome from bovine mammosphere-derived cells (MDC) promotes angiogenesis, epithelial cell migration, and contains factors associated with defense and immunity. Sci Rep 8: 5378.

\section{Your next submission with Juniper Publishers will reach you the below assets}

- Quality Editorial service

- Swift Peer Review

- Reprints availability

- E-prints Service

- Manuscript Podcast for convenient understanding

- Global attainment for your research

- Manuscript accessibility in different formats

( Pdf, E-pub, Full Text, Audio)

- Unceasing customer service

Track the below URL for one-step submission https://juniperpublishers.com/online-submission.php 